\title{
SNS Characteristics of Mobile Communication Company Influencing Brand Attitude and Purchase Intention
}

\author{
Sukkyun Hong ${ }^{1} \&$ Inchae Park $^{2}$ \\ ${ }^{1}$ Department of Smart Convergence Consulting, Hansung University, Seoul, South Korea \\ ${ }^{2}$ Division of Smart Management Engineering, Hansung University, Seoul, South Korea \\ Correspondence: Inchae Park, Assistant Professor, Division of Smart Management Engineering, Hansung University, \\ 116 Samseongyoro-16gil, Seongbuk-gu, Seoul, 02876, South Korea. Tel: 82-10-5485-4559. E-mail: \\ ipark@ hansung.ac.kr
}

Received: April 9, 2020

Accepted: May 9, 2020

Online Published: May 23, 2020

doi:10.5430/rwe.v11n2p82

URL: https://doi.org/10.5430/rwe.v11n2p82

\begin{abstract}
Background/Objectives: The purpose of this study is to investigate the influence of SNS characteristics on brand attitude and purchase intention as the importance of SNS marketing is increasing recently.

Methods/Statistical analysis: The subjects of this study were consumers who have visited SNS of domestic mobile carriers in recent years. Data collection was conducted online. A total of 31 questions were included, including 6 general characteristics and 25 questions on the Likert 5-point scale. The collected data was utilized by SPSS Ver.22 statistical package for empirical analysis. The main analyzes were frequency analysis, validity, reliability, and multiple regression analysis.

Findings: This study examined the effect of mobile carrier SNS characteristics on the purchase intention and empirically analyzed whether the brand attitude had a mediating effect on the relationship between SNS characteristics and purchase intention. The empirical results show that the measured variables correlate with each other. First, SNS characteristics have a positive effect on purchase intention. As a result of multiple regression analysis, the standardization coefficient $(\beta)$ showed that information providing had the highest influence on purchase intention as $.355^{* * * *}$. The explanatory power $\left(\mathrm{R}^{2}\right)$ of the relationship between SNS characteristics and purchase intention was .485 $(48.5 \%)$. Second, SNS characteristics have a positive effect on brand attitude. Benefit had the highest impact on brand attitude of $.418^{* * *}$. The explanatory power $\left(\mathrm{R}^{2}\right)$ of SNS characteristics on the influence of brand attitude was .538 (53.8\%). Third, brand attitude affects purchase intention. Finally, Brand attitude was partially mediated between SNS characteristics and purchase intention. The characteristics of SNS are important to increase purchase intention, and the mediating effect of brand attitude is verified.
\end{abstract}

Improvements/Applications: This study emphasizes the importance of SNS characteristics through brand attitude to increase purchase intention. It will be an important resource for suggesting SNS marketing methods that effectively utilize SNS characteristics.

Keywords: SNS characteristic, brand attitude, purchase intension, SNS marketing

\section{Introduction}

The recent development of SNS (Social Network Services) has greatly influenced corporate marketing strategies. Many companies use SNS to communicate with customers and analyze them for marketing strategies. Mobile carriers try to increase consumer intentions by promoting products and services while communicating with customers online via SNS. SNS users purchase products that are suitable for them while comparing mobile communication products and services. Mobile carriers can quickly observe user preferences and inconveniences on SNS to quickly accept and process them. SNS marketing is recognized as a management activity that enhances the competitiveness of mobile carriers. Despite the importance of SNS marketing, research on SNS marketing academia in the field of mobile carriers is still insufficient. The purpose of this study is to examine which factors, such as information providing, interactivity, and benefit, which are SNS characteristics, influence the brand attitude and purchase intention of mobile carriers more importantly. 


\section{Materials and Methods}

\subsection{SNS Characteristics}

SNS(Social Network Sites) is defined as a web-based service that configures an individual's profile, shares connections formed through relationships between individuals, and supports interactions between individuals based on those connections (Boyd and Ellison, 2007). Recently, with the popularization of smartphones, the number of SNS users is rapidly increasing, and the importance of marketing activities using SNS is increasing. SNS marketing has the advantage of being able to deploy real-time marketing activities to the global market without the limitation of time and space online. As a result, SNS marketing is becoming more and more aware of its importance, and this trend is expected to accelerate further. In this changing environment, companies will be able to secure more competitive advantage in the market by using SNS marketing more actively. Studies that measure the effects of SNS marketing mainly deal with SNS characteristics as independent variables, and the attitudes and behavioral indicators of SNS users are used to measure the effects. In this paper, SNS characteristics are classified into three categories: information providing, interactivity, and benefit. Information providing is defined as the characteristic that SNS receives and shares useful information so that consumers can make easier final decisions about products and services (Smith and Swinyard, 1982). Interactivity is the degree of reaction through SNS users' messages and information. And it can be defined as the process of exchanging messages and information (Rafaeli and Sudweeks, 1997). Interactivity is a vehicle for building good relationships with consumers and is the most fundamental element that increases customer engagement (Fortin and Dholakia, 2005). Benefit is defined as a feature that allows users to receive information and services on products more easily and quickly through SNS, thus reducing the time spent searching for information and making decisions (Bachiochi et al., 1997). The user can purchase the product at a low price by directly receiving a benefit through promotions, events and discount coupons of the product (Hassanein and Head, 2005).

\subsection{Brand Attitude}

Brand attitude is defined as the feeling that an individual feel about the brand as positive or negative, favorable or unfavorable, positive or negative (Fishbein and Ajzen). Brand attitude is a comprehensive evaluation factor that consumers feel about a brand, and it is an important criterion that affects the buying behavior of consumers choosing a specific brand (Keller, 2003). Brand attitude is an important factor of consumer behavior that directly affects consumer's purchasing behavior, and it is important because brand attitude, once formed, is not easily changed but is stable and continuously maintained.

\subsection{Purchase Intension}

Purchase intention is an area of behavioral intention, which is the individual's will and belief realized by future behavior as a result of the attitude that the individual has made toward a particular company (Mitchell and Olson, 1981). Many previous studies have pointed out a close correlation between purchasing intention and actual purchasing behavior. Therefore, purchase intention can be used as a prediction of actual buying behavior (Shin et al., 2012).

\subsection{The Research Model and Hypothesis}

\subsubsection{Research Model}

The purpose of this study is to identify the relationship between SNS characteristics and brand attitude, and purchase intention based on theoretical considerations of previous studies. As SNS characteristics, information providing, interactivity, and benefit were selected as independent variables. Brand attitude was chosen as a parameter. The purchase intention was selected as the dependent variable. Based on these previous studies, hypotheses were set up to analyze the effect of SNS characteristics on purchase intention. The research model for this study is shown in [Figure $1]$. 


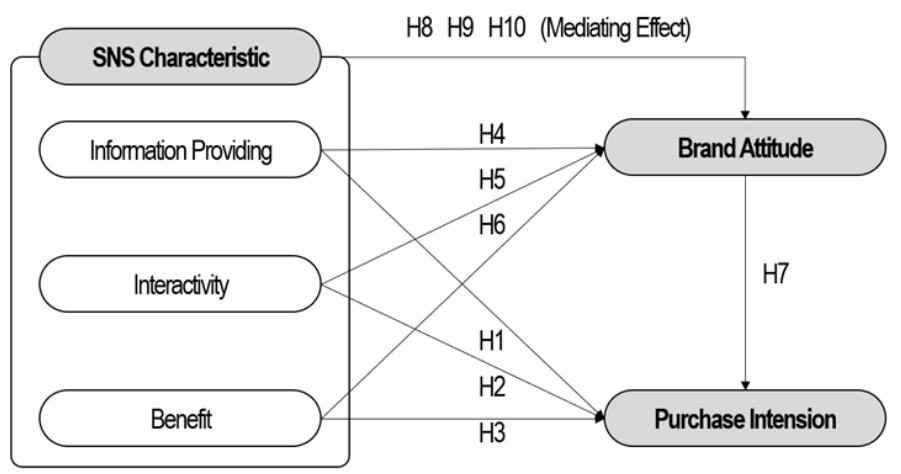

Figure 1. Research model

\subsubsection{Research Hypothesis}

Based on the research model shown in [Figure 1], the hypothesis about the relationship between SNS characteristics and purchase intention was set. Next, a research hypothesis was established about the mediating effect of brand attitude on the relationship between SNS characteristics and purchase intention.

H1. Information providing will have a positive effect on purchase intention.

H2. Interactivity will have a positive effect on purchase intention.

H3. Benefits will have a positive effect on purchase intentions.

H4. Information providing will have a positive effect on brand attitude.

H5. Interactivity will have a positive effect on brand attitude.

H6. Benefits will have a positive effect on brand attitude.

H7. Brand attitude will have a positive effect on purchase intentions.

H8. Brand attitude will mediate the impact of information providing on purchasing intentions.

H9. Brand attitude will mediate the impact of interactivity on purchasing intentions.

H10. Brand attitude will mediate the relationship between benefits and purchase intentions.

\subsubsection{Operational Definition of Variables}

Based on the results of previous studies, this study divided 15 SNS characteristics into information providing, interactivity, and benefit to construct a total of 15 questionnaires. Five measures of brand attitude and purchase intention were adapted according to the purpose of this study. The operational definition of each variable and the composition of the questionnaire are summarized as shown in [Table 1].

Table 1. Operational definition of variables

\begin{tabular}{|c|c|c|c|c|}
\hline $\begin{array}{l}\text { Evaluation } \\
\text { items }\end{array}$ & $\begin{array}{l}\text { Measurement } \\
\text { variable }\end{array}$ & Operational definition & $\begin{array}{l}\text { Configure } \\
\text { questionnaire }\end{array}$ & Researcher \\
\hline \multirow{3}{*}{$\begin{array}{c}\text { SNS } \\
\text { Characteristics }\end{array}$} & $\begin{array}{l}\text { Information } \\
\text { providing }\end{array}$ & $\begin{array}{c}\text { Diversity, Accuracy, Usefulness, Promptness, } \\
\text { Interesting }\end{array}$ & 5 questions & $\begin{array}{l}\text { (Smith and } \\
\text { Swinyard, } \\
\text { 1982) }\end{array}$ \\
\hline & Interactivity & $\begin{array}{c}\text { Communication, Information exchange, Reaction, } \\
\text { Customer Consultation, Comment }\end{array}$ & 5 questions & $\begin{array}{l}\text { (Rafaeli and } \\
\text { Sudweeks, } \\
\text { 1997), } \\
\text { (Fortin and } \\
\text { Dholakia, } \\
\text { 2005) }\end{array}$ \\
\hline & Benefit & Easy to search, Price discount, Time saving, & 5 questions & (Bachiochi \\
\hline
\end{tabular}




\begin{tabular}{cccc} 
Brand Attitude & $\begin{array}{c}\text { Brand } \\
\text { Attitude }\end{array}$ & $\begin{array}{c}\text { Good impression, Friendliness, Trust, Satisfaction, } \\
\text { Attention }\end{array}$ & $\begin{array}{c}\text { 5 questions } \\
(\text { Keller, } \\
\text { 2003) }\end{array}$ \\
\hline $\begin{array}{c}\text { Purchasing } \\
\text { Intension }\end{array}$ & $\begin{array}{c}\text { Purchase } \\
\text { Intension }\end{array}$ & $\begin{array}{c}\text { Service information, Communication, Price, } \\
\text { (Mitchell }\end{array}$ & $\begin{array}{c}\text { and Olson, } \\
\text { Experience, Event, }\end{array}$ \\
& & 1981); (Shin \\
et al., 2012)
\end{tabular}

\section{Results and Discussion}

\subsection{Empirical Results}

\subsubsection{Demographic Characteristics Analysis}

In this study, a total of 302 samples were used to collect data from consumers who have experienced SNS within the last year. In order to understand the distribution of collected samples, frequency analysis of general characteristics was conducted. The frequency analysis showed that $45.0 \%$ (136) were male and $55.0 \%$ (166) were female. The age-specific characteristics were highest in the 30s (34.4\%), followed by $32.1 \%$ (97) in the $40 \mathrm{~s}$, and $27.8 \%$ (84) in the 50s and over. The highest level of education was $46.4 \%$ (140), and the next was 44.7\% (135). The occupation was 14.9\% (45), followed by $13.6 \%$ (41), and $11.6 \%$ (35) officials. The average income was $23.2 \%$ (70) with less than $3 \sim 4$ million won. The number of visits was the most frequent with $3 \sim 5$ visits $(47.7 \%, 144)$.

\subsubsection{Descriptive Analysis}

In this study, the descriptive statistical analysis of the collected data showed that the standard deviation was 3 or less, the skewness statistical value 3 or less, and the kurtosis statistical value 3 or less. Individual measures of 25 questionnaires were analyzed to ensure normality (Roukiane and Marzouki, 2018); (Salim and Hariandja, 2018).

\subsubsection{Exploratory Factor Analysis and Reliability Analysis}

An exploratory factor analysis was conducted to test the validity of individual measurement variables. Principal component analysis was used, and the rotation method was Varimax method. The eigenvalue was set to 1.0 or higher as a selection criterion for the measurement variable. In this study, factor analysis was conducted twice. Finally, the KMO index is 0.936, above the normal level of 0.7. The result of Bartlett's unit matrix is 0.000, which is smaller than the general level of 0.05 , which is 0.000 , which makes it suitable for exploratory factor analysis. Interactivity 4 and interactivity 5 that inhibit discriminant validity and concentration validity were removed and classified into 5 factors. Reliability analysis analyzed Cronbach's alpha coefficient for Internal Consistency Reliability to secure homogeneity between measured variables obtained from exploratory factor analysis. As a result of reliability analysis, Cronbach 's alpha coefficient of all the measured variables is over 0.6, which is a general level, and it is judged that reliability is secured even if the separate item is not removed. The summary of the exploratory factor analysis and the reliability analysis of the measurement variables for the questionnaire is shown in [Table 2].

Table 2. Exploratory factor analysis and reliability analysis

\begin{tabular}{|c|c|c|c|c|c|c|c|}
\hline \multirow{2}{*}{$\begin{array}{l}\text { Measurement } \\
\text { item }\end{array}$} & \multicolumn{5}{|c|}{$\begin{array}{l}\text { Exploratory factor analysis (Intensive validity \& Discriminant } \\
\text { validity) }\end{array}$} & \multirow{2}{*}{ Commonality } & \multirow{2}{*}{$\begin{array}{c}\text { Reliability } \\
\text { analysis }\end{array}$} \\
\hline & Benefit & $\begin{array}{l}\text { Purchase } \\
\text { Intension }\end{array}$ & $\begin{array}{c}\text { Brand } \\
\text { Attitude }\end{array}$ & $\begin{array}{l}\text { Information } \\
\text { providing }\end{array}$ & Interactivity & & \\
\hline Benefit 3 & .777 & .156 & .229 & .214 & .115 & .739 & \multirow{4}{*}{.880} \\
\hline Benefit 2 & .766 & .205 & .140 & .089 & .140 & .676 & \\
\hline Benefit 5 & .742 & .228 & .168 & .123 & .184 & .679 & \\
\hline Benefit 4 & .734 & .188 & .260 & .140 & .123 & .677 & \\
\hline
\end{tabular}




\begin{tabular}{|c|c|c|c|c|c|c|c|}
\hline Benefit 1 & .685 & .179 & .278 & .239 & -.036 & .638 & \\
\hline $\begin{array}{c}\text { Purchase } \\
\text { Intension } 2\end{array}$ & .192 & .763 & .210 & .270 & .071 & .741 & \multirow{5}{*}{.892} \\
\hline $\begin{array}{c}\text { Purchase } \\
\text { Intension } 4\end{array}$ & .252 & .757 & .250 & .279 & .115 & .790 & \\
\hline $\begin{array}{c}\text { Purchase } \\
\text { Intension } 3\end{array}$ & .284 & .724 & .216 & .174 & .145 & .703 & \\
\hline $\begin{array}{l}\text { Purchase } \\
\text { Intension } 5\end{array}$ & .222 & .712 & .277 & .207 & .143 & .697 & \\
\hline $\begin{array}{l}\text { Purchase } \\
\text { Intension } 1\end{array}$ & .135 & .676 & .273 & .134 & .172 & .597 & \\
\hline $\begin{array}{c}\text { Brand } \\
\text { Attitude } 2\end{array}$ & .251 & .263 & .756 & .172 & .167 & .762 & \multirow{5}{*}{.888} \\
\hline $\begin{array}{c}\text { Brand } \\
\text { Attitude } 3\end{array}$ & .217 & .298 & .733 & .259 & .094 & .749 & \\
\hline $\begin{array}{c}\text { Brand } \\
\text { Attitude } 4\end{array}$ & .234 & .265 & .727 & .184 & .147 & .709 & \\
\hline $\begin{array}{c}\text { Brand } \\
\text { Attitude } 5\end{array}$ & .334 & .260 & .651 & .141 & .233 & .676 & \\
\hline $\begin{array}{c}\text { Brand } \\
\text { Attitude } 1\end{array}$ & .327 & .298 & .543 & .244 & .127 & .566 & \\
\hline $\begin{array}{l}\text { Information } \\
\text { providing } 1\end{array}$ & .196 & .157 & .107 & .771 & .086 & .677 & \multirow{5}{*}{.851} \\
\hline $\begin{array}{l}\text { Information } \\
\text { providing } 3\end{array}$ & .272 & .186 & .043 & .742 & .105 & .672 & \\
\hline $\begin{array}{l}\text { Information } \\
\text { providing } 4\end{array}$ & .171 & .242 & .269 & .714 & .114 & .683 & \\
\hline $\begin{array}{l}\text { Information } \\
\text { providing } 5\end{array}$ & .196 & .293 & .339 & .692 & .113 & .731 & \\
\hline $\begin{array}{l}\text { Information } \\
\text { providing } 2\end{array}$ & -.040 & .143 & .225 & .602 & .340 & .550 & \\
\hline $\begin{array}{c}\text { Interactivity } \\
1\end{array}$ & .103 & .104 & .117 & .081 & .801 & .683 & \multirow{3}{*}{.678} \\
\hline $\begin{array}{l}\text { Interactivity } \\
2\end{array}$ & .096 & .110 & .272 & .189 & .710 & .636 & \\
\hline $\begin{array}{c}\text { Interactivity } \\
3\end{array}$ & .304 & .267 & .037 & .254 & .575 & .559 & \\
\hline Eigenvalue & 3.673 & 3.534 & 3.247 & 3.201 & 1.937 & & \\
\hline $\begin{array}{c}\% \text { of } \\
\text { Variance }\end{array}$ & 15.972 & 15.363 & 14.118 & 13.918 & 8.421 & & \\
\hline $\begin{array}{c}\% \text { of } \\
\text { Accumulated }\end{array}$ & 15.972 & 31.335 & 45.453 & 59.371 & 67.793 & & \\
\hline \multicolumn{2}{|c|}{$\begin{array}{l}\text { Kaiser-Meyer-Olkin } \\
\text { Sample Fit. }\end{array}$} & & & & & & .936 \\
\hline \multicolumn{2}{|c|}{ Bartlett's unit matrix test } & $\begin{array}{l}\text { Approximate } \\
\text { Chi Square }\end{array}$ & 4106.873 & $\mathrm{df}$ & 253 & p-value & 0.000 \\
\hline
\end{tabular}




\subsubsection{Correlation Analysis}

Through exploratory factor analysis, this study eliminated measurement items that impeded concentration and discriminant validity and secured one-dimensionality. It consisted of five variables that were calculated by averaging among the measured variables that had homogeneity through reliability analysis. Correlation analysis was performed to determine the degree of directionality and density among the measured variables (Sharif, 2019); (Smail, 2019). In Table 3, the correlation between the measurement variables showed that the information providing ability was highly correlated with purchase intentions as $.602^{* *}$, followed by the brand attitude as $.595^{* *}$. The brand attitude was shown to have a high correlation coefficient of $.646^{* *}$ for benefit, followed by a correlation between information providing and $.595^{* *}$. Purchase intention was highest in the positive direction, with $.699^{* * *}$ and brand attitude. Next, there was a correlation between information providing and $.602^{* *}$. The correlation analysis results of all the measured variables showed statistically significant positive correlations. It is judged that it is possible to analyze the causal relationship among the constructs. A summary of the correlation analysis results is shown in [Table 3].

Table 3. Summary of correlation analysis results

\begin{tabular}{ccccccccc}
\hline Constructs & $\mathrm{N}$ & Mean & $\begin{array}{c}\text { Standard } \\
\text { Deviation }\end{array}$ & $\begin{array}{c}\text { Information } \\
\text { providing }\end{array}$ & Interactivity & Benefit & $\begin{array}{c}\text { Brand } \\
\text { Attitude }\end{array}$ & $\begin{array}{c}\text { Purchase } \\
\text { Intension }\end{array}$ \\
\hline $\begin{array}{c}\text { Information } \\
\text { providing }\end{array}$ & 302 & 3.980 & 0.617 & 1 & $.491^{* *}$ & $.507^{* *}$ & $.595^{* *}$ & $.602^{* *}$ \\
\hline Interactivity & 302 & 3.640 & 0.690 & $\mathbf{. 4 9 1} 1^{* *}$ & 1 & $.433^{* *}$ & $.509^{* *}$ & $.472^{* *}$ \\
\hline Benefit & 302 & 3.597 & 0.619 & $\mathbf{. 5 0 7 * *}$ & $\mathbf{. 4 3 3} * *$ & 1 & $.646^{* *}$ & $.586^{* *}$ \\
\hline $\begin{array}{c}\text { Brand } \\
\text { Attitude }\end{array}$ & 302 & 3.856 & 0.631 & $\mathbf{. 5 9 5 * *}$ & $\mathbf{. 5 0 9 * *}$ & $\mathbf{. 6 4 6 * *}$ & 1 & $.699^{* *}$ \\
\hline $\begin{array}{c}\text { Purchase } \\
\text { Intension }\end{array}$ & 302 & 3.805 & 0.646 & $\mathbf{. 6 0 2 * *}$ & $\mathbf{. 4 7 2 * *}$ & $\mathbf{. 5 8 6 * *}$ & $\mathbf{. 6 9 9 * *}$ & 1 \\
\hline
\end{tabular}

**. The correlation is significant at the .01 level (both sides).

\subsubsection{Hypothesis Test Result}

To test the hypothesis of this study, multiple regression analysis was performed using the SPSS ver.22 statistical package. [Table 4] shows that Durbin-Watson is 2.129 in the relationship between SNS characteristics and purchase intention, 2.130 in SNS characteristics and brand attitude, and 2.067 in the relationship between brand attitude and purchase intention. Independence was secured. The VIF (Dispersion Expansion Coefficient) indexes are all less than 10 , indicating that there is no multicollinearity between independent variables. The independence of the independent variables is ensured, making it suitable for multiple regression analysis. In the relationship between the consultant's SNS characteristics and purchase intention, the non-standardized coefficient (B) showed that the SNS characteristics had a positive effect on the purchase intention. Hypotheses H1, H2, and H3 hypotheses were all adopted. Next, the standardization coefficient $(\beta)$ shows that information providing has the highest influence on purchase intention, which is $.355^{* * *}$. The explanatory power $\left(\mathrm{R}^{2}\right)$ of the relationship between SNS characteristics and purchase intention was .485 $(48.5 \%)$. Next, looking at the non-standardized coefficient (B) in the relationship between the consultant's SNS characteristics and brand attitude, it was found that SNS characteristics had a positive effect on brand attitude. Hypotheses H4, H5, and H6 hypotheses were all adopted. Next, the standardized coefficient $(\beta)$ showed the highest impact on brand attitude as $.418^{* * *}$. The explanatory power $\left(\mathrm{R}^{2}\right)$ of SNS characteristics on the influence of brand attitude was $.538(53.8 \%)$. Finally, in the relationship between brand attitude and purchase intention, the non-standardized coefficient (B) showed that brand attitude had a positive effect on purchase intention. Hypothesis $\mathrm{H} 7$ was adopted. The explanatory power $\left(\mathrm{R}^{2}\right)$ on the influence of brand attitude on purchase intention was .488 (488\%). [Table 4] summarizes the hypothesis test between SNS characteristics and purchase intention, the hypothesis test between SNS characteristics and brand attitude, and the hypothesis test between brand attitude and purchase intention through multiple regression analysis. 
Table 4. Summary of multi- regression analysis results

\begin{tabular}{|c|c|c|c|c|c|c|c|}
\hline $\begin{array}{l}\text { Hypothes } \\
\text { is }\end{array}$ & Constructs & B & $\beta$ & $\mathrm{t}$ & $\mathrm{p}$-value & VIF & Results \\
\hline & (Constant) & 0.531 & & 2.681 & .008 & & \\
\hline H1 & Information providing & .372 & .355 & 6.903 & .000 & 1.533 & accept \\
\hline $\mathrm{H} 2$ & Interactivity & .140 & .150 & 3.043 & .003 & 1.402 & accept \\
\hline $\mathrm{H} 3$ & Benefit & .356 & .341 & 6.859 & .000 & 1.432 & accept \\
\hline \multicolumn{8}{|c|}{$\mathrm{R}^{2}=.485$, Adjusted $\mathrm{R}^{2}=.480, \mathrm{~F}=93.457(\mathrm{p}=<.001)$, Durbin-Watson=2.129, Dependent variable $:$ Purchase Intension } \\
\hline & (Constant) & 0.521 & & 2.845 & .005 & & \\
\hline H4 & Information providing & .300 & .293 & 6.011 & .000 & 1.533 & accept \\
\hline H5 & Interactivity & .168 & .184 & 3.945 & .000 & 1.402 & accept \\
\hline H6 & Benefit & .426 & .418 & 8.873 & .000 & 1.432 & accept \\
\hline \multicolumn{8}{|c|}{$\mathrm{R}^{2}=.538$, Adjusted $\mathrm{R}^{2}=.533, \mathrm{~F}=115.727(\mathrm{p}=<.001)$, Durbin-Watson=2.130, Dependent variable $:$ Brand Attitude } \\
\hline & (Constant) & 1.044 & & 6.312 & .000 & & \\
\hline $\mathrm{H} 7$ & Brand Attitude & .716 & .699 & 16.920 & .000 & & accept \\
\hline
\end{tabular}

\subsubsection{Mediated Effect Analysis}

In order to analyze the mediating effect of brand attitude on the relationship between SNS characteristics and purchase intention, multiple regression analysis was performed using Baron \& Kenny's three-step approach. First, in step 3, the information providing, and benefit were analyzed to partially mediate brand attitude in the relationship of SNS characteristics to purchase intention. Hypotheses H8 and H10 for the mediated effect analysis were adopted. [Table 5] summarizes the analysis results of the mediator effect of brand attitude on purchase intention by consultant's SNS characteristics. Hypothesis $\mathrm{H} 7$ was adopted. The explanatory power $\left(\mathrm{R}^{2}\right)$ on the influence of brand attitude on purchase intention is .563 (56.3\%). Comparing Step 1 and Step 3 shows the change in the standardization coefficient ( $\beta$ ) for the mediating effect of brand attitude in the relationship of SNS characteristics to purchase intention. Due to the mediating effects of brand attitude, the standardization coefficient $(\beta)$ has information providing $(.355, \mathrm{p}<.001 \rightarrow .235, \mathrm{p}<.001)$, benefit $(.341, \mathrm{p}<.001 \rightarrow .169, \mathrm{p}<.01)$ was reduced.

Table 5. Summary of mediating effects of branding attitude in SNS characteristics and purchase intension

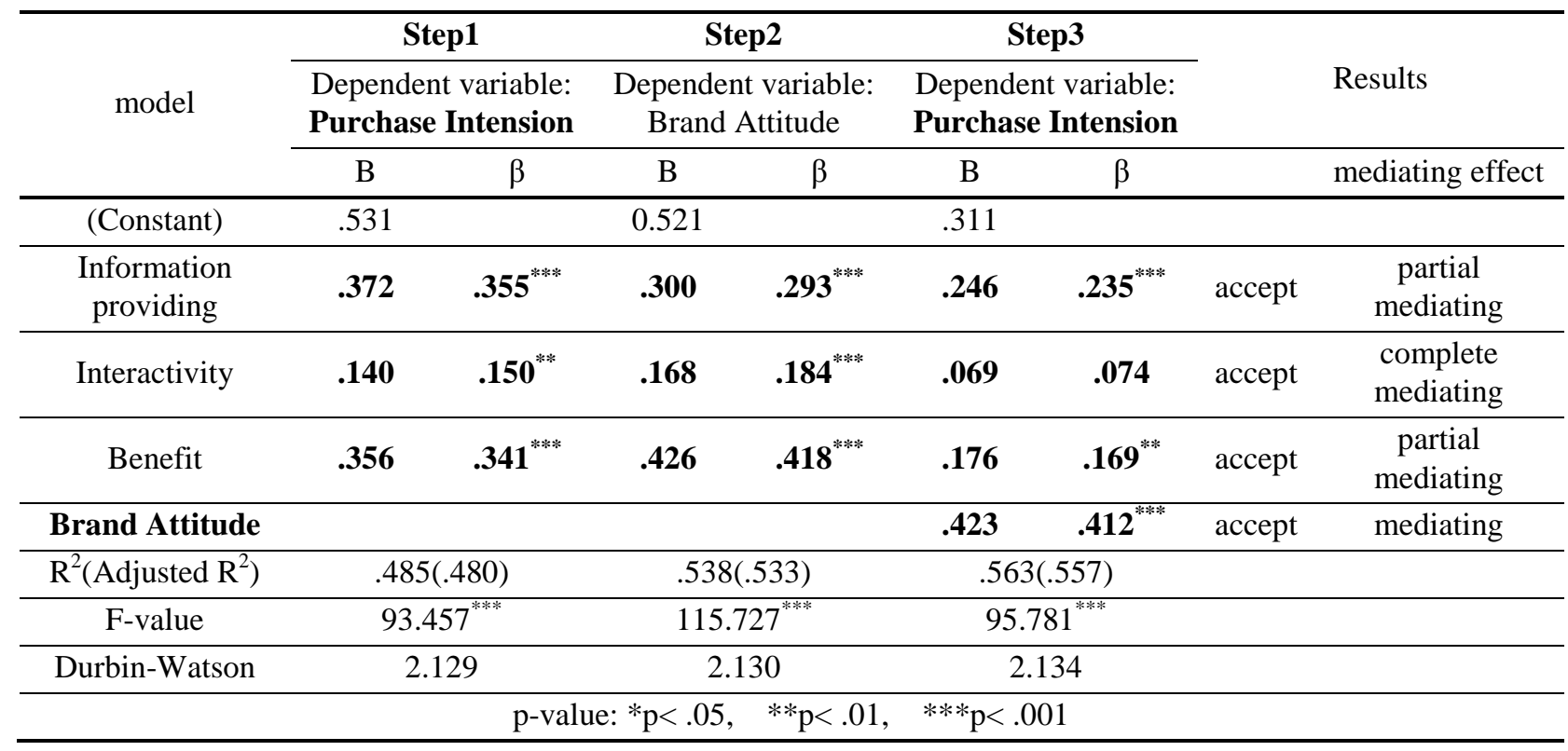




\section{Conclusion}

This study derives information providing, interactivity, and benefit as major factors among SNS characteristics of mobile carriers. In addition, this study examined the relationship between the carrier's SNS characteristics on brand attitude and purchase intention. As a result, among SNS characteristics of mobile carriers, information providing had the most influence on purchase intention. Various information and accurate and prompt information had a positive effect on purchase intention. Mobile operators should try to deliver a variety of information quickly and accurately through SNS. In addition, benefit had the most influence on brand attitude. The SNS feature, which saves time due to the convenience of search, discounted price, and economic benefits through events, has a positive effect on brand attitude. Like other previous studies, it was verified that brand attitude plays a role in purchasing intention. Mobile carriers can improve their brand and increase sales through SNS. This study has great significance in that it can contribute to the effect of SNS marketing management using SNS characteristics of mobile carriers. In addition, it is of great academic significance in that it provides useful basic data to mobile carriers doing SNS marketing activities to help them establish SNS marketing strategies.

\section{Acknowledgment}

This research was financially supported by Hansung University.

\section{References}

Bachiochi, D., Berstene, M., Chouinard, E., Conlan, N., Danchak, M., Furey, T., ... Way, D. (1997). Usability studies and designing navigational aids for the World Wide Web. Computer Networks and ISDN Systems, 29(8-13), 1489-96.

Boyd, D. M., \& Ellison, N. B. (2007). Social network sites: Definition, history, and scholarship. Journal of Computer-Mediated Communication, 13(1), 210-30.

Fishbein, M., \& Ajzen, I. (1997). Belief, attitude, intention, and behavior: An introduction to theory and research. Contemporary Sociology, 6(2).

Fortin, D. R., \& Dholakia, R. R. (2005). Interactivity and vividness effects on social presence and involvement with a web-based advertisement. Journal of Business Research, 58(3), 387-96.

Hassanein, K., \& Head, M. (2005). The impact of infusing social presence in the web interface: An investigation across product types. International Journal of Electronic Commerce, 10(2), 31-55.

Keller, K. L. (2003). Understanding brands, branding and brand equity. Interactive Marketing, 5(1), 7-20.

Mitchell, A. A., \& Olson, J. C. (1981). Are product attribute beliefs the only mediator of advertising effects on brand attitude. Journal of Marketing Research, 18(3), 318-32.

Rafaeli, S., \& Sudweeks, F. (1997). Networked interactivity. Journal of Computer-Mediated Communication, 2(4), 243.

Roukiane, B., \& Marzouki, A. E. (2018). Maturities and dynamic volatility of sukuk comparative study between a sukuk and a conventional bond index. Asian Development Policy Review, 6(4), 226-242.

Salim, M. N., \& Hariandja, N. M. (2018). Factors affecting joint stock price index (CSPI) and the impact of foreign capital investment (PMA) Period 2009 to 2016. Humanities and Social Sciences Letters, 6(3), 93-105.

Sharif, S. H. (2019). The impact of capital structure on stock return of selected firms in the pharmaceutical and chemical sector in Bangladesh. International Journal of Social Sciences Perspectives, 5(1), 9-21. https://doi.org/10.33094/7.2017.2019.51.9.21

Shin, M. H., Oh, S. H., Hwang, D. Y., Seo, S. S., \& Kim, Y. C. (2012). Effect of SNS characteristics on consumer satisfaction and purchase intention of Agri-Food contents. The Journal of the Korea Contents Association, 12(11), 358-67.

Smail, R. A. (2019). Non-governmental organizations participations and tactics in Kurdistan regions commission of integrity lawmaking. International Journal of Social and Administrative Sciences, 4(2), 267-276.

Smith, R. E., \& Swinyard, W. R. (1982). Information response models: An integrated approach. Journal of Marketing, 46(1), 81-93. 